\title{
GLUCOSE LEVEL ANALYSIS ON STORED PACKED RED CELLS
}

\author{
Melissa Heidy Wongsari, Rachmawati Muhiddin, Mansyur Arif \\ Department of Clinical Pathology, Faculty of Medicine, Hasanuddin University/Wahidin Sudirohusodo Hospital, \\ Makassar, Indonesia. E-mail: melissa_heidy@yahoo.com
}

\begin{abstract}
The main source of energy for red cell metabolism is glucose via glycolytic pathway. Red cells metabolism slows down during storage at 2-60C. Biochemical changes during storage are called storage lesions, i.e. decreased $\mathrm{pH}$, glucose, and ATP, lactic acid accumulation, and loss of red cells function. Samples taken from the tip of PRC bags in CPDA-1 of the same code are divided into four sections, and stored in the blood bank refrigerator at 2-60C. Glucose level is measured using ABX Pentra 400 (Horiba, Japan) on storage day 3 as a control, day 7 , day 14 , and day 21 . Glucose levels during storage decreased significantly between day 3 , and day 7 ( $p<0.001)$, between day 7, and day $14(p<0.001)$, and between day 14, and $21(p<0.001)$. Glucose levels of Packed Red Cells (PRC) decrease during storage. Glycolysis occurs during storage although metabolism slows down.
\end{abstract}

Keywords: Packed red cells, stored blood, glucose

\section{INTRODUCTION}

Blood transfusion is a process of delivering blood or blood components from a donor to a recipient. Blood transfusion activity aims to improve the quality of life of patients by generating oxygen transportability, improving its circulation, increasing blood components, or enhancing blood clotting function. Whole blood or blood components (blood cellular components, and plasma components) are transfused. Packed Red Cells (PRC) is the most widely used blood component in the world. In PRC, red blood cell is considered as the most important component. ${ }^{1-3}$

To store the blood components for long periods of time, the anticoagulant preservative is used since it cannot generate adverse effects on the quality of red blood cells, including Acid-Citrate-Dextrose $(A C D)$, Citrate-Phosphate-Dextrose (CPD), CitratePhosphate-Dextrose-Dextrose (CP2D), and CitratePhosphate-Dextrose-Adenine (CPDA-1). Citrate (sodium citrate, and citric acid) acts as an anticoagulant, whereas phosphate, adenine, and dextrose are substrates for cellular metabolism. ACD, CPD, and CP2D, thus, allow the storage of red blood cells for 21 days, while the retention of red blood cells in CPDA- 1 reaches to 35 days. The most commonly used anticoagulant preservative in the United states, and Indonesia is CPDA-1. Citrate-PhosphateDextrose-Adenine (CPDA-1) is composed of 26.30 grams of trisodium citrate, 3.27 grams of citric acid, 2.22 grams of sodium dihydrogen phosphate, 31.8 grams of dextrose, 0.275 grams of adenine, and 1 liter of water. A total of $14 \mathrm{~mL}$ of CPDA-1 is usually added to every $100 \mathrm{~mL}$ of blood taken. ${ }^{1,4-7}$

Moreover, red blood cells do not have mitochondria; therefore the breakdown of glucose, known as glycolysis process, is the only source of energy for red blood cells. The end product of this glycolysis process is lactate. In the glycolysis process, adenosine triphosphate (adenosine triphosphate, ATP) is needed as a source of energy. Adenosine triphosphate will lose one inorganic phosphate, and convert to adenosine diphosphate (adenosine diphosphate, ADP). The next process is re-forming of ATP, in which each glucose molecule will produce two ATP molecules. Adenosine triphosphate production then will decrease as the slowing of red blood cell metabolism during storage and as all red blood cell functions require energy. ${ }^{6,7}$

Furthermore, the storage of blood in blood banks at temperatures between $2-6^{\circ} \mathrm{C}$ can slow the metabolism of red blood cells. Biochemical changes in the stored blood may occur although the temperatures between $2-6^{\circ} \mathrm{C}$ can affect the viability and function of red blood cells. This change is called as storage 
lesion, including a decrease in $\mathrm{pH}$, a decrease in glucose levels, accumulation of lactic acid, a decrease in ATP levels and loss of red blood cell function. In other words, storage lesion can decrease red cell viability so that it cannot be transfused. ${ }^{5,6,8}$ Therefore, the preservative aims to minimize the effect of such biochemical changes and maximize the time to store the blood components.

Similarly, a research conducted by D'Alessandro et al., ${ }^{9}$ found that the accumulation of glycolytic metabolites in the first seven days of storage can trigger the process of glycolysis, then slowing down over time of storage. As the previous research, a research conducted by Flatt et al.,. ${ }^{10}$ also revealed that the decreased concentration of glycolytic metabolites could indicate the slowing of glycolysis process. ${ }^{9.10}$ Unfortunately, researches on glucose levels in stored PRC still have not yet been done in Makassar. As a result, this research aimed to determine the effect of storage on blood glucose levels of PRC.

\section{METHODS}

This research was a prospective cohort study conducted during August 2015. The collecting of data began when blood bags were distributed from the Regional Blood Transfusion Unit (UPTD) of South Sulawesi Province to the Blood Bank of the Dr.Wahidin Sudirohusodo Hospital. Those blood bags were stored in the refrigerator of the Blood Bank of the Dr.Wahidin Sudirohusodo Hospital at a temperature of $2-6^{\circ} \mathrm{C}$. The code number of those blood bags, the date of blood sampling on those blood bags, and the expired date of blood were documented. Hoses from blood bags with the same code number were divided into four sections. After that, the blood bags were examined on the third, seventh, fourteenth, and twenty-first days from the dates of blood sampling. Clotted, and lysed blood samples were excluded from this research.

Next, whole blood samples taken from the cut blood bag hoses were transferred into test tubes without anticoagulant, and then centrifuged for 15 minutes at 3,000 rpm. Afterward, the plasma was then put into sample cups, and then the glucose levels were examined using a glucose oxidase method with ABX Pentra 400 tool (Horiba, Japan) at the Clinical Pathology Laboratory, Emergency Department of the Dr. Wahidin Sudirohusodo Hospital in Makassar. Those samples then were checked based on their st- orage age. After that, the data were analyzed by Friedman test, and continued with post hoc test - Wilcoxon. Results then were displayed in tables, and graphs.

\section{RESULTS AND DISCUSSION}

Each of those fifty samples was examined four times in this research, i.e. glucose level measurements on the third day as a control, seventh, fourteenth, and twenty-first days from the dates of blood sampling. Distribution, and differences in blood glucose levels $(\mathrm{mg} / \mathrm{dL})$ of PRC based on storage time can be seen in Table 1, and Figure 1. Results of this research showed that the mean blood glucose level on the third day was $526.84 \mathrm{mg} / \mathrm{dL}$. On the seventh day, the mean blood glucose level decreased to 458.72 $\mathrm{mg} / \mathrm{dL}$. On the fourteenth day, the mean blood glucose level decreased again to $380.39 \mathrm{mg} / \mathrm{dL}$. On the twenty-first day, the mean blood glucose level decreased to the lowest one, about $307.90 \mathrm{mg} / \mathrm{dL}$.

Moreover, results of the Shapiro Wilk test indicated that the data of blood glucose levels collected on the third, seventh, fourteenth, and twenty-first days from the dates of blood sampling were not normally distributed $(p<0.05)$ as illustrated in Table 1. Thus, a non-parametric test, Friedman's ANOVA test or often called Friedman test, was performed. Results of the Friedman test revealed that there was a significant difference in the mean blood glucose levels bet-

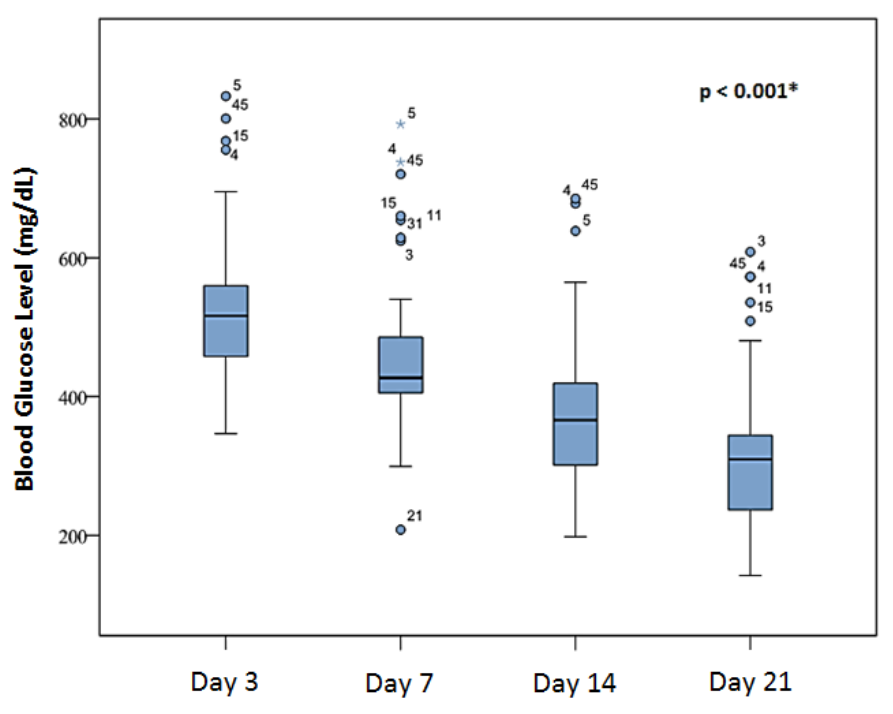

Figure 1. Box plot of blood glucose distribution $(\mathrm{mg} / \mathrm{dL})$ based on the storage time

* Friedman test: $p<0.05$; significant 
ween the third, seventh, fourteenth, and twenty-first days from the dates of blood sampling $(p<0.05)$. Post hoc test then was performed to compare the mean blood glucose levels among the groups.

Furthermore, results of the Post Hoc test found that there were differences in the mean blood glucose levels $(\mathrm{mg} / \mathrm{dL})$ among the groups as shown in Table 2. There was a difference in the mean blood glucose level as much as $68.114 \mathrm{mg} / \mathrm{dL}$ between on day 3, and day $7(95 \% \mathrm{Cl}: 50.539-85.688)$. There was also a difference in the mean blood glucose level as much as $78.333 \mathrm{mg} / \mathrm{dL}$ between on day 7 , and day 14 (95\% Cl: 60.711 - 95.954). Similarly, there was a difference in the mean blood glucose level as much as $72.486 \mathrm{mg} / \mathrm{dL}$ between on day 14 , and day 21 ( $95 \% \mathrm{Cl}: 50.737$ - 94.236). Besides, there were significant differences in the mean blood glucose level among the groups, such as between on day 3 , and day 7 , between on day 7 , and day 14 , as well as between on day 14, and day 21 .

Table 1. Distribution, and differences in blood glucose levels $(\mathrm{mg} / \mathrm{dL})$ of PRC $(\mathrm{N}=50)$ based on the storage time $(\mathrm{mg} / \mathrm{dL})$

\begin{tabular}{lcll}
\hline \multirow{2}{*}{$\begin{array}{c}\text { PRC stor- } \\
\text { age time }\end{array}$} & $\begin{array}{c}\text { Blood glucose } \\
(\mathbf{m g} / \mathrm{dL})\end{array}$ & $\begin{array}{c}\text { Normality } \\
\text { test }\end{array}$ & $\begin{array}{c}\text { Comparison } \\
\text { test }\end{array}$ \\
\cline { 2 - 4 } Mean \pm SD & \multicolumn{1}{c}{ p-value } & p-value \\
\hline Day 3 & $526.84 \pm 107.16$ & $0.001^{*}$ & \\
Day 7 & $458.72 \pm 111.66$ & $<0.001^{*}$ & \\
Day 14 & $380.39 \pm 115.78$ & $0.004^{*}$ & $<0.001^{* *}$ \\
Day 21 & $307.90 \pm 113.65$ & $0.002^{*}$ & \\
\hline
\end{tabular}

*Shapiro-Wilk test: $\mathrm{p}<0.05$; data distribution not normal **Friedman test: $p<0.05$; significant

By the standard of blood storage based on the Regulation of the Minister of Health of the Republic of Indonesia number 91 of 2015 on Blood temperature of $2-6^{\circ} \mathrm{C}$. After measured, the mean blood glucose level of PRC on the third day was $526.84 \mathrm{mg} / \mathrm{dL}$ with a standard deviation of 107.16 $\mathrm{mg} / \mathrm{dL}$, while the mean blood glucose level on day 7 was $458.72 \mathrm{mg} / \mathrm{dL}$ with a standard deviation of $111.66 \mathrm{mg} / \mathrm{dL}$. Besides, the mean blood glucose level on day 14 was $380.39 \mathrm{mg} / \mathrm{dL}$ with a standard deviation of $115.78 \mathrm{mg} / \mathrm{dL}$, whereas the mean blood glucose level on day 21 was $307.90 \mathrm{mg} / \mathrm{dL}$ with a standard deviation of $113.65 \mathrm{mg} / \mathrm{dL}$. The decreased blood glucose levels indicated the occurrence of glycolysis process. ${ }^{11,12}$

In addition, red blood cells cannot produce energy through the Krebs cycle or oxidative pathways since they have no cell nucleus, and mitochondria; thus depending on other metabolic pathways, especially: Embden-Meyerhof pathway (glycolysis), anaerobic glucose breakdown, and ATP yield; the Hexose Monophosphate line, which produces NADPH to protect red blood cells from oxidative injury; the Rapoport-Luebering pathway, producing 2,3-diphosphoglycerate (2,3-DPG) which plays a role in the regulation of oxygen affinity. ${ }^{9,13,14}$ The main energy source for red blood cell metabolism is glucose generated through glycolysis process. The glycolysis process breaks one molecule of glucose into two molecules of ATP.

Under normal circumstances at room temperature $\left(25^{\circ} \mathrm{C}\right)$, the glycolysis process will decrease blood glucose levels in vitro by $5-10 \mathrm{mg} / \mathrm{dL}$ per hour, whereas at a temperature of $2-6^{\circ} \mathrm{C}$ red blood cells metabolism decelerates so that blood can survive during storage in the bank blood. Similarly, the results of this research also indicated that glucose levels in PRC were significantly decreased from day 3 to day 7 ( $p$ $<0.001$ ), from day 7 to day 14 ( $p<0.001)$, and from day 14 to day $21(p<0.001)$. $^{13,15,16}$

Glucose consumption, according to D'Ales-

Table 2. Results of the Post Hoc test on the mean blood glucose levels $(\mathrm{mg} / \mathrm{dL}$ ) based on the storage time

\begin{tabular}{ccccc}
\hline Storage time (i) & Comparison (j) & $\begin{array}{c}\text { Mean } \\
\text { difference (i-j) }\end{array}$ & $\begin{array}{c}\text { 95\% Cl } \\
\text { (min-max) }\end{array}$ & value \\
\hline Day 3 (control) & Day 7 & 68.114 & $50.539-85.688$ & $<0.001^{*}$ \\
Day 7 & Day14 & 78.333 & $60.711-95.954$ & $<0.001^{*}$ \\
Day 14 & Day 21 & 72.486 & $50.737-94.236$ & $<0.001^{*}$ \\
\hline
\end{tabular}

*Non-Parametric Pos Hoc Test: Wilcoxon Signed Rank Test: $p<0.05$ : significant

Transfusion Service Standard, PRC blood bags were stored in blood storage refrigerators in the Blood Bank of the Dr.Wahidin Sudirohusodo Hospital at a sandro, occurs gradually, but it is constant over the storage period, i.e. almost half at the end of storage. 
Similarly, Burger et al.,. ${ }^{15}$ reported a decrease of 0.6 times on the $35^{\text {th }}$ day of storage. These results suggested that glucose consumption is not inhibited during storage, and the glucose levels even are higher than the needs of the cells. 9,14

At the beginning of blood storage, ATP level tends to be fixed or slightly increased. ATP level reaches its peak within two weeks of storage time, and then decreases to less than $50 \%$ at the end of storage time. The process of glycolysis requires ATP. When ATP decreases or runs out, as a result, the glycolysis process stops. ${ }^{5,15,17}$

Furthermore, the red blood cell membrane, and $\mathrm{Hb}$ function depend on energy produced in the red cell metabolic pathway. Adenosine triphosphate is an important source of energy to maintain electrolyte balance through $\mathrm{Na}+/ \mathrm{K}+$ pump, and also plays a role in maintaining the phospholipid membrane as well as the shape and flexibility of red blood cells. Changes in the shape of red blood cells may occur due to decreased ATP levels during storage, along with decreased lipid content and increased cell rigidity. The most noticeable change in red blood cells during storage is a change in the cell phenotype, which varies from discoid, echinocyte (cells with protrusions or spicules on the cell membrane), to spheroechinocyte (spheroidal cells). ${ }^{14}$

D'Alessandro et al., ${ }^{9}$ in his paper also stated that glycolytic metabolites are congested in the first week of storage, and then decline over storage time. On the other hand, lactate as the end product of red blood cell metabolism has increased during storage. The use of glucose, and lactate production is negatively correlated.

Acidity or $\mathrm{pH}$ is an important marker of red blood cell metabolism during storage that declines as $\mathrm{pH}$ decreases. Lactate accumulation occurs during the storage period indicating that glycolysis does not stop. $^{9,14}$

Rapoport-Luebering pathway, a branch of the glycolytic pathway, converts 1,3-DPG to 2,3-DPG, thereby linking energy metabolism with the affinity of hemoglobin to oxygen. During the storage of red blood cells, 2,3-DPG level will decrease rapidly, and deplete within two weeks. This decrease is related to $\mathrm{pH}$. In blood bags, there is a decrease in $\mathrm{pH}$ due to lactate accumulation. Therefore, 1,3-DPG intermediate glucose metabolite is converted by mutase to 2,3 -DPG, and then dephosphorylated by phosphatase into 3-phosphoglycerate.
Phosphatase enzyme becomes inactive at a $\mathrm{pH}$ of more than 7.2, but becomes more active at low $\mathrm{pH}$; As a result, the concentration of 2,3-DPG decreases drastically. $5,17,18$

In addition, the half-life of red blood cells in the circulation is $120 \pm 4$ days, but the standard storage duration for red blood cells using a CPI-1 anticoagulant-preservative is 35 days. The red blood cells in the blood bags, however, have a much shorter half-life. As many as $25 \%$ of the transfused blood cell components will disappear from the circulation within 24 hours after-transfusion. This is because the donated blood contains red blood cells that are old, so at the time of storage blood cells just complete the process of maturation become too old when transfused. Also, storage conditions are very different from the normal physiological state. Consequently, red blood cell storage time is determined by the time period required by these cells to produce lactic acid that decreases the $\mathrm{pH}$ to 6.5 , resulting in decreased, and insufficient ATP production to ensure cell viability. Low ATP levels can also lead to a change from normal discoid red blood cell into echinocytes. ${ }^{14,19,20}$

Finally, the process of glycolysis aims to produce ATP. Storage lesion, including the slowing down of the glycolysis process during the storage can lead to a decrease in ATP production. In other words, the blood glucose levels of PRC can indirectly indicate the ATP levels during the storage. Nevertheless, this research still had some limitations, such as not measuring ATP levels and/or assessing the morphology of red blood cells during storage simultaneously.

\section{CONCLUSION AND SUGGESTION}

In conclusion, there was a difference in blood glucose concentration of Packed Red Cells (PRC) on days $3,7,14$, and 21 . The decreased blood glucose concentration may be due to storage effects, one of which is glycolysis process during storage. Besides, the blood glucose level of PRC also indirectly indicates ATP level during the storage. Low ATP level can affect the integrity of cell membranes, and the viability of red cells. As a result, it is recommended to use PRC with a short storage period compared to PRC for long storage periods since the bioavailability of red blood cells decreases with storage duration. 


\section{REFERRENCES}

1. Sudiono H, Iskandar I, Edward H, Halim SL, Santoso R. Transfusi Darah. Dalam: Penuntun Patologi Klinik Hematologi. Cetakan ketiga. Jakarta, Bagian Patologi Klinik Fakultas Kedokteran Ukrida. 2009; 200-5.

2. I Made Bakta. Transfusi Darah. Dalam: Hematologi Klinik Ringkas. Jakarta, EGC. 2003; 271-3.

3. Liumbruno GM, AuBuchon JP. Old blood, new blood or better-stored blood? Blood Transfusion. 2010; 8(4): 217-9. doi: 10.2450/2010.0060-10.

4. Greene $\mathrm{CE}$, Hillyer $\mathrm{CD}$. Component Preparation and Manufacturing. In: Hillyer CD, Shaz BH, Zimring JC, Abshire TC, editors. Transfusion Medicine and Hemostasis - Clinical, and Laboratory Aspects. New York, Elsevier, 2009; 48-50.

5. Campbell-Lee SA, Ness PM. Packed Red Blood Cells, and Related Products. In: Hillyer CD, Silberstein LE, Ness PM, Anderson KC, Roback JD, editors. Blood Banking and Transfusion Medicine. $2^{\text {nd }}$ Ed., Philadephia, Elsevier, 2007; 250-3.

6. Klein HG, Anstee DJ, editors. The transfusion of red cells. In: Mollison's Blood Transfusion in Clinical Medicine. $11^{\text {th }}$ Ed., Massachusetts, Blackwell Science, 2005; 363-76.

7. Harmening DM, Moroff G. Red Blood Cell, and Platelet Preservation: Historical Perspective, Review of Metabolism and Current Trends. In: Harmening DM. Modern Blood Banking and Transfusion Practices. $5^{\text {th }}$ Ed., Philadelphia, FA Davis Company, 2005; 1-12.

8. Blaney KD, Howard PL, editors. Blood Component Preparation, and Therapy. In: Basic and Applied Concepts of Blood Banking and Transfusion Practices. $3^{\text {rd }}$ Ed., Missouri, Elsevier, 2013; 304-9.
9. D'Alessandro A, D'Amici GM, Vaglio S, Zolla L. Timecourse investigation of SAGM-stored leukocytefiltered red blood cell concentrates: from metabolism to proteomics. Hematologica, the Hematology Journal, 2012; 97(1): 107-115. doi:10.3324/ haematol.2011.051789.

10. Flatt JF, Bawazir WM, Bruce LJ. The involvement of cation leaks in the storage lesion of red blood cells. Frontiers in physiology. 2014; 5: 214. doi: 10.3389/ fphys.2014.00214.

11. Olivier R. Red Blood Cell Microparticles: Role in Transfusion Medicine? [PhD thesis]. Lausanne: University of Lausanne; 2011 [cited 2015 Aug 1]. Available from:

University of Lausanne Open Archive http:// serval.unil.ch

12. Solinge WW, Wijk R. Enzymes of the Red Blood Cell. In: Burtis CA, Ashwood ER, Bruns DE. Tietz Textbook of Clinical Chemistry and Molecular Diagnostics. $5^{\text {th }}$ Ed., Missouri, Elsevier Saunders, 2012; 599-608.

13. D'Alessandro A. Red Blood Cell Ageing in vivo and in vitro: the Integrated Omics Perspective [Ph.D thesis]. Viterbo: Universita' Degli Studi Della Tuscia, 2013 [cited 2015 Aug 1]. Available from: http:// www.centronazionalesangue.it

14. Yoshida T, Shevkoplyas SS. Anaerobic Storage of Red Blood Cells (Review). Blood Transfus, 2010; 8(4): 22036. doi: 10.2450/2010.0022-10.

15. Burger $\mathrm{P}$, Korsten $\mathrm{H}$, Verhoeven AJ, Korte $\mathrm{D}$, Bruggen R. Collection and Storage of Red Blood Cells with Anticoagulant, and Additive Solution with a Physiologic pH. Transfusion. 2012; 52(6):1242-52. doi: 10.1111/ j.1537-2995.2011.03472.x.

16. D'Alessandro A, Kriebardis AG, Rinalducci S, Antonelou $\mathrm{MH}$, Hansen KC, Papassideri IS, et al. An Update on Red Blood Cell Storage Lesions, as Gleaned through biochemistry and omics technologies. Transfusion. 2014; 1-15. doi: 10.1111/trf.12804. 